Agnieszka Kwiatek-SoŁtys, Krzysztof Wiedermann

Pedagogical University of Cracow, Poland

Helene Mainet, Jean-Charles Edouard

Blaise Pascal University, Clermon-Ferrand, France

\title{
The Role of Industry in Satellite Towns of Polish and French Metropolitan Areas - Case Study of Myślenice and Issoire
}

\begin{abstract}
The emerging problem of changing and shrinking economic base of many small towns causes necessity of searching for new paths of development for them. Former central service functions existing in many small towns are largely washed out to larger cities as a result of thepresent metropolisation processes. The question arises to what extent these towns are or may be attractive for the development of production functions.

The aim of the paper is to show the role of industry for the development of small towns in Małopolska in Poland and Auvergne in France on the case studies of Myślenice and Issoire.
\end{abstract}

Key words: economic zones; industrial parks; metropolitan areas; satellite towns; small towns

\section{INTRODUCTION}

Economic processes taking place today lead to structural and spatial changes in industry. They cover both areas of most developed countries in Europe, as well as the countries of Central Europe, where the process of transformation started at the beginning of the ' $90 \mathrm{~s}$. The most important factors should be on the one hand, a gradual process of globalization of production and the associated relocation of industrial plants, and on the other hand, automation of manufacturing processes will reduce the importance of labor in the manufacture of industrial products.

In the case of countries which the process of economic transformation concerns, changes in the industrial structure were much broader, because the structure of production in the period of centrally planned economy and the level of technological products differ considerably from market expectations after the opening of the borders in 1989. In addition, the industry in the centrally planned economy was nationalized. The consequence of this was a big change in existing manufacturing companies which included the organizational and ownership area and changes in the modernization both in products and in the process of their manufacturing. It is worth stressing that earlier production did not take place on a market basis, and standards related to environmental protection required changes due to the large industrial emissions (Rajman, 2001). 
Metropolitan areas are very attractive ones for the location of the new exogenous functions to which the industry belongs (Rachwat, 2012b). The most important competitive factors of these places are good transport accessibility, large resources and diverse structure of the workforce and of course much wider market. Metropolitan areas are characterized by relatively high property prices in relation to the peripheral areas, but, nevertheless, the lowest prices of their land are specific to outdoor areas. In the case of the production activity it has a significant importance due to its land consumption that is dealing with a relatively large surface area needed for building factories. This facilitates the relocation processes of existing production resources from urban core areas to those located on the outskirts of metropolitan area. This process is particularly noticeable in the countries of the former socialist bloc, because the lack of proper rent from the point of view of free-market economics ground meant that many manufacturing plants developed in urban centers. Since the ' 90 s, they have been converted to service areas and the production is transferred outside the densely populated central parts of cities.

Metropolisation processes and leaching of central functions to the core areas make it necessary to find new paths of development of small towns. The industry seems to be a good solution from the perspective of especially the case of satellite towns located close to major transport routes to ensure adequate accessibility. The development of industry in cities not only provides direct and indirect benefits to the local economy and the local labor market but also improves the fiscal situation of municipalities (Domański, 2004; Domański et al., 2005; Domański, Gwosdz, 2010; Rachwał, Wiedermann, 2008; Stryjakiewicz (ed.), 2005; Wiedermann, 2008). For this reason, more and more often in case of these towns the need to build industrial parks could be noticed (Jarczewski, Huculak, 2011; Rachwał, 2012a).

In the paper the towns of two provinces are examined. One is Myślenice in Małopolska in Poland and the second one is Issoire in Auvergne in France. The provinces seem to be similar due to their geographical location within the country, the diversity of landscape and the functions of cities and towns together with the communication accessibility. The settlement structure of both provinces is dominated by the province capital city. The settlement network of Auvergne is dominated by Clermont-Ferrand and in Małopolska Kraków is the biggest and the most important city (Rajman, 2000, 2001). In the settlement structure of both provinces small towns play a dominant role as they make $87 \%$ of all cities in Auvergne and $77 \%$ in Małopolska.

CASE STUdy OF MYŚLENICE: A SMALl DistriCt MULTIFUNCTIONAL TOWN WITHIN THE KRAKÓW METROPOLITAN AREA

Myślenice is a town located $30 \mathrm{~km}$ to the south of Kraków at the Raba river. The town is surrounded by the hills of Pogórze Wielickie and Beskid Makowski. The town is situated at the country road E77 called "Zakopianka", connecting Kraków to Zakopane and the country 
border passes in the south. The road between Kraków and Zakopane is a motorway, which makes the connection to the province's capital very easy.

The history of Myślenice comes back to the middle ages. The first written document dated 1253-1258 says about the settlement with the fortress. The settlement next to the fortress was given its Magdeburg city rights in 1342. Rights given to Myślenice by the king Casimir the Great to make the city developed caused the changes of its location from the former Stradom part to the present Rynek (market square) area. The later history of the town brings the school in the $15^{\text {th }}$ century, clothiers at the beginning of the $16^{\text {th }}$ century and the poorhouse. In 1629 Myślenice were seriously damaged by the fire and later on in 1655 by Swedes. After 1772 Myślenice were incorporated in the Austrian partition. The imperial tract connecting Vienna and Lviv caused the revival of trade and the development of the town.

The town became the district town in 1866 - the gymnasium was built and the town was developed. The dam on Raba river was built in 1921 what caused the growth of the recreational function on so-called "Zarabie", where many beautiful villas were built. This function was strengthened when the road from Kraków to Myślenice was finished. After the Second World War the former village Chełm was incorporated in town and the new housing estates were built. The role of the industry was strengthened by the localization of new factories.

The spatial structure of the town is divided into few separate parts. The old part with the market square (Fig. 1 and 2) surrounded by the $18^{\text {th }}$ and the $19^{\text {th }}$ century houses is located on the left river bank of Raba. The historical buildings of the inn, the manor house, the parish church can be found here. The south part of the town on the right river side is occupied by the earlier mentioned recreation part of the town with a new sport and recreation infrastructure including the sport and recreation center, shooting range, skate park and tennis courts (Fig. 3). The nearby town's park was newly reconstructed. The road "Zakopianka" separates the old town center from the industrial zone.

The demographic situation of the town reflects its economic development (KwiatekSoltys, 2011). However, the demographic changes follow the unfavorable tendencies in terms of aging processes, the emigration, the lower natural growth in towns, but the towns is gaining new inhabitants every year (Kwiatek-Sołtys, 2004).

Myślenice is a small town inhabited by over 18,000 people. The population dynamic for the town between years 2002-2012 is positive and the value 102,7 is close to the average for small towns in the province. The higher dynamic is characteristic only for towns in the direct influence of Kraków (Niepołomice, Wieliczka). The population growth of the town is caused by the natural growth 3,1\% (average for years 2002-2012), while the average migration balance ratio is $-2,2 \%$. The higher level of natural growth indexes is still traditionally characteristic for the south of Poland, where on the one hand there is a very religious society, and on the other hand this is an area of a long term and long origin emigration, especially to USA and Austria. The population of the town is aging quickly. The share of children (aged 0-14) decreased from $18,6 \%$ in 2002 to $15,8 \%$ in 2012 while the share of $65+$ inhabitants increased from $11,5 \%$ to $14,9 \%$ in 2012 . The positive factor, however, is the stable share of mobile working population group (40,7\% in 2002 and $40,1 \%$ in 2012), which means that the labor force of Myślenice has not been aging yet. 


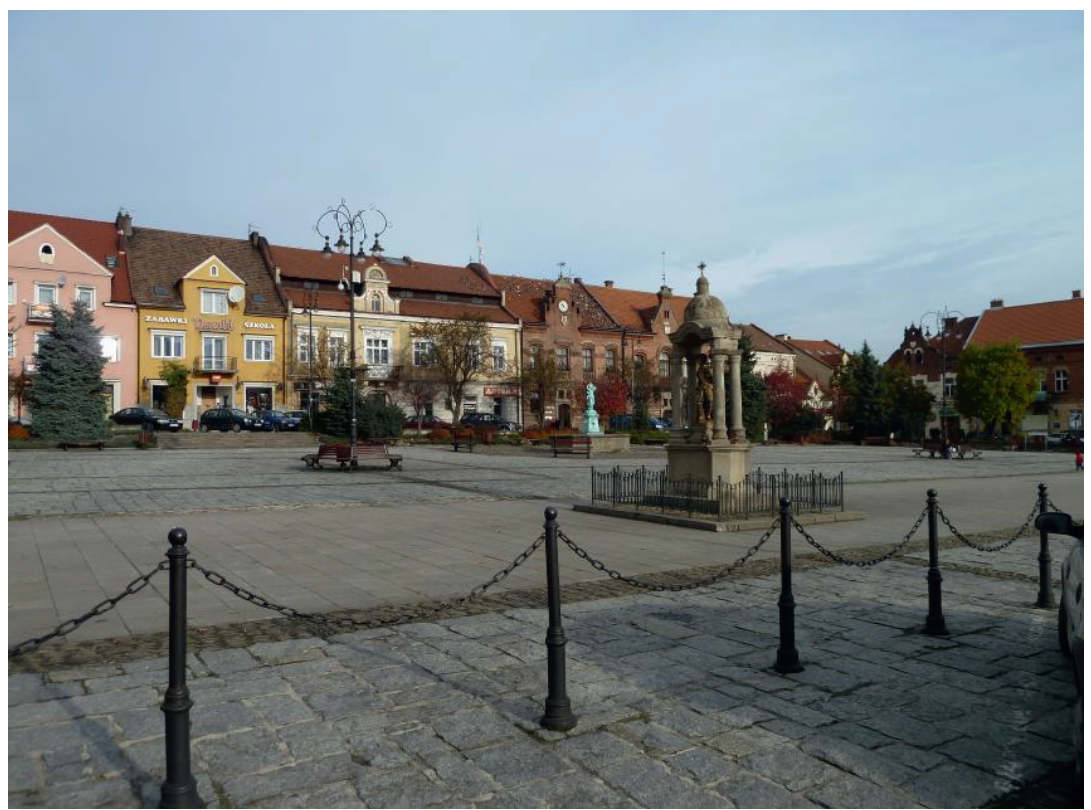

Fig. 1. Myślenice - market square

Photo: A. Kwiatek-Sołtys

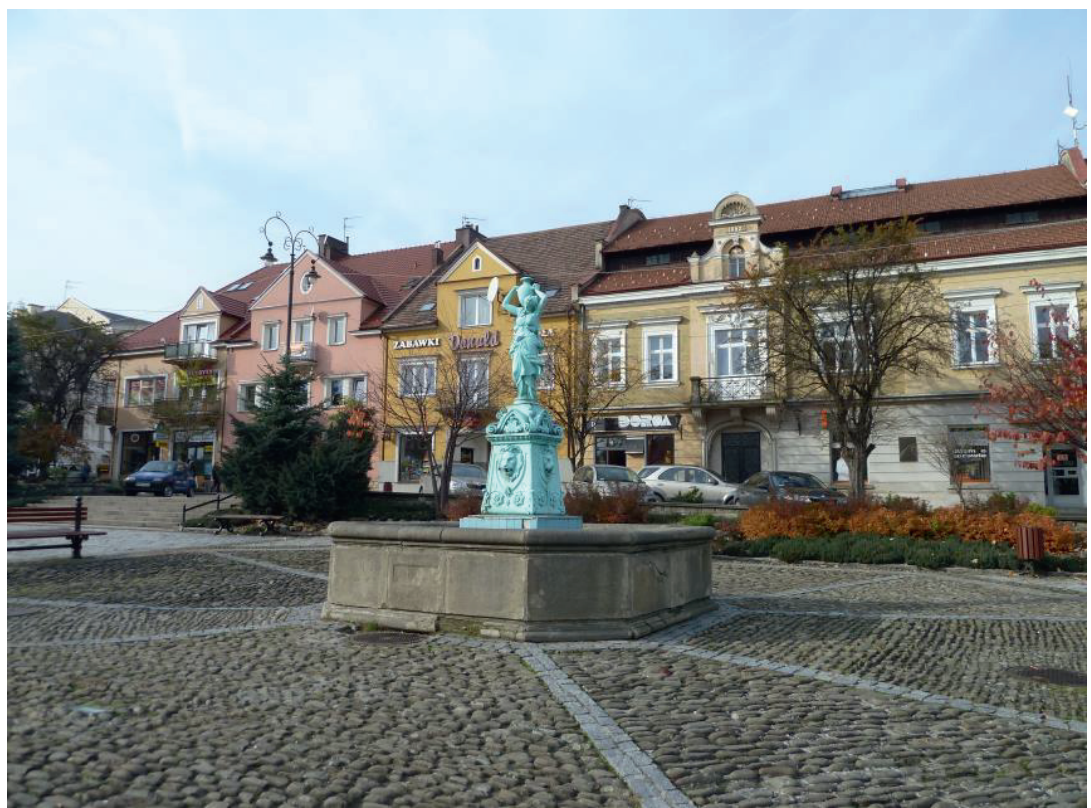

Fig. 2. Myślenice - market square

Photo: A. Kwiatek-Sołtys 


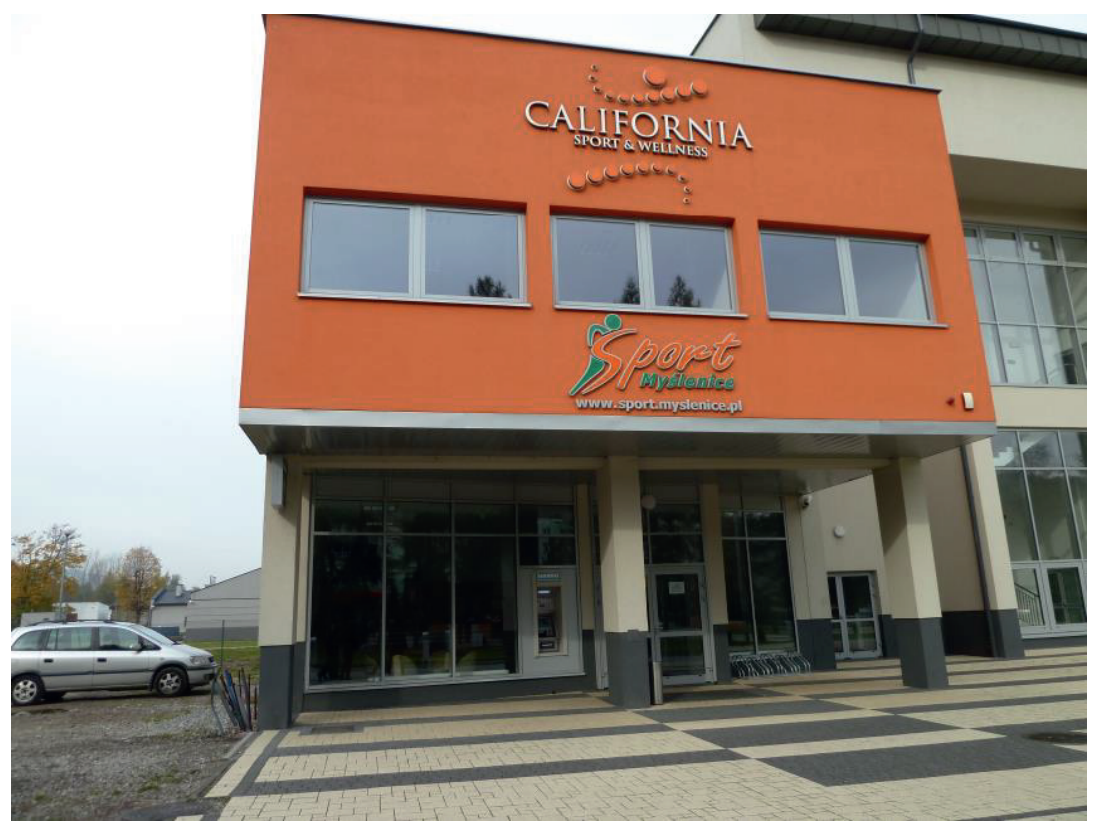

Fig. 3. Myślenice - new sport center

Photo: A. Kwiatek-Sołtys

Myślenice is a seat of a district. It is a cultural, sport and commercial center for the whole commune. There are 3040 registered economic units in the town and over $78 \%$ of this number are different services. The number of services is increasing (by 213 between 2009 and 2012). However, the employment structure of the town differs, as the service sector employs $58,8 \%$ of all working population of the town while industry and construction over $40 \%$.

Industry was also an important factor influencing the growth of the town. In the history apart from trade craft was developed. Broadcloth, glass production, pottery were among popular activities. In the interwar period there were hat and shoes factories, mill, sawmill and a brewery.

The development of the post war industry was influenced by the localization of a branch of Kraków's big cloth factory "Vistula" in the "70s. In 1992 a new big factory was established in Myślenice called Tele-Fonika s.c. It produces copper telecommunication cables, fiber optic computer cables and car cables. There are many smaller production firms in the town as well. Many of them represent the metal industry and some are international ones (ex. Gubad with the German capital employing over 100 workers in 2008).

There are 98 hectares of industry area in the town and more than twice of that in the commune (Fig. 4). The beginning of the $21^{\text {st }}$ century was the time of the opening of the economic activity zone (Katowice Special Economic Zone) in Myślenice. Starting from 2000 the area has been equipped with the necessary infrastructure. Myślenice gained the UE money for creating and equipping the zone. Cooper Standard Automotive Polska (a producer of 
car accessories) was the first big factory in the zone in 2007. The company previously conducted business in Bielsko-Biała and was looking for a new location for the development of its activities in the vicinity of Kraków. After a few meetings with local authorities Myślenice occurred to be the best choice for the second plant in Poland. After the success of Cooper Standard Automotive Polska other important firms appeared (Polplast Polska Sp. z o.o. or suits producer Lorens\&Wiktor).

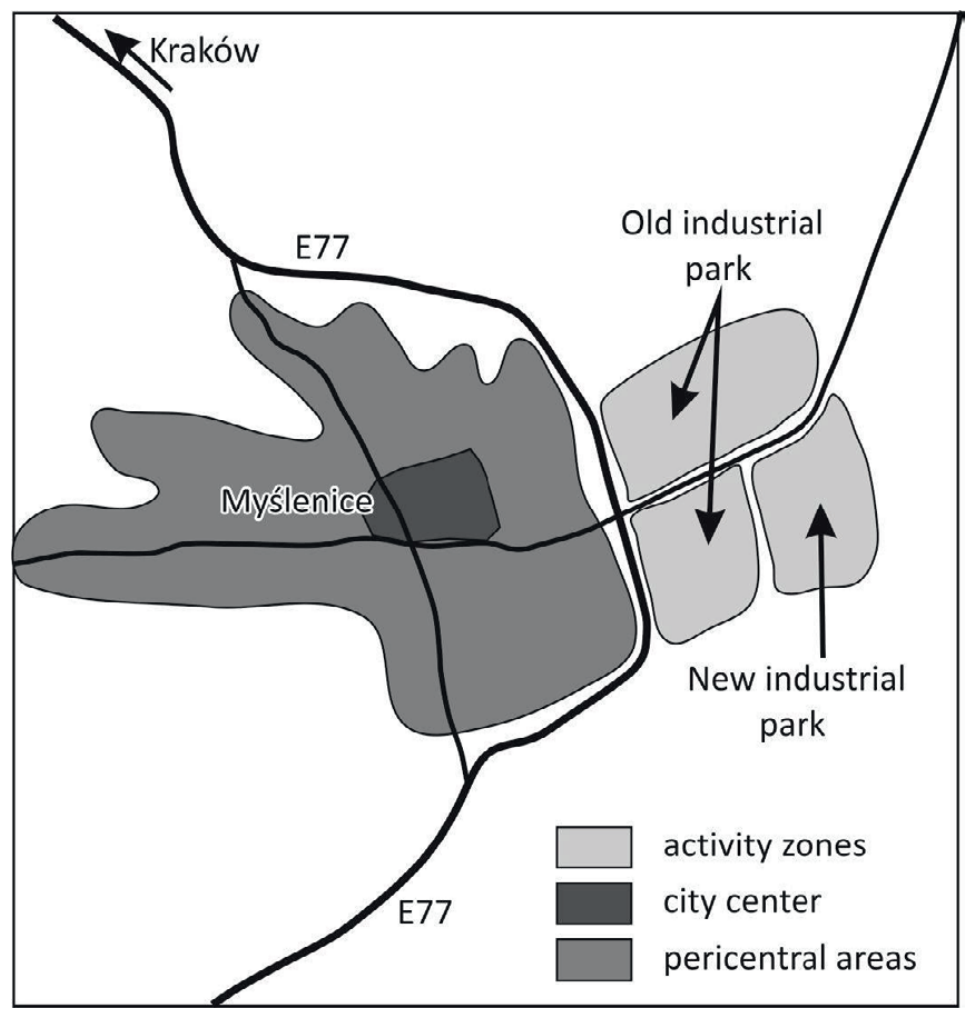

Fig. 4. Industrial zone in Myślenice

Source: own elaboration by K. Wiedermann

CASE STUDY OF ISSOIRE: AN INDUSTRIAL SMALL TOWN NOW CONNECTED TO METROPOLITAN DYNAMISM

Issoire is a small town located 38 kilometers to the south of Clermont-Ferrand in the plain South Limagne at the confluence of Allier and Couze Pavin Rivers. The town is also located at the contact to the Volcans d'Auvergne and Livradois Forez regional parks. Issoire is easily accessible with the nearby motorway A75 Clermont-Ferrand-Montpellier and a line 
SNCF Paris-Nîmes-Béziers. In 2010, the town was inhabited by 14,771 people living on 26 square kilometers, when the urban area was inhabited by 26,367 people ${ }^{1}$.

The history of the town goes back to the $6^{\text {th }}$ century when Gregory of Tours designated Ysiodorum or vicus Isiodorensis. The medieval city was growing next to the Benedictine Abbey and St. Austell church. In 1270 Issoire received the municipal charter by Alphonse de Poitiers. The $15^{\text {th }}$ century Issoire was a well developed town with a right to three markets. Later the town was destroyed by religious wars and the plaque. It was, however, quickly rebuilt and became a district town with a post office and two parishes. The fortifications were demolished in the $18^{\text {th }}$ century. In the second part of the $18^{\text {th }}$ century Issoire was a town of 5000 inhabitants but its economic situation was rather bad.

The period extending from 1789 to 1792 was marked by significant economic and political difficulties due to the outbreak of the French Revolution. After the revolution Issoire became a main town of a district. La Halle was built, the place of grain selling. In the Abbey building the college was placed what made Issoire the important center of education in the department. A very important role for the development of the town was a railway connection opened in 1855. By the end of the century the present town hall was built. In the $19^{\text {th }}$ and at the beginning of the $20^{\text {th }}$ centuries Issoire was a large agricultural and trade town.

The first half of the $20^{\text {th }}$ century brought new functions to the town: a garrison town and industrial activities. Shortly before the First World War, Wassmer Aviation was located in the town.

In the thirties the Ducellier institutions raised their factories in Issoire and production was only for national defense purpose. In 1939, Forgeal and the Central Society of Light Alloys (SCAL) settled in the suburbs. The choice of Issoire was linked with a need of grouping for the production, a strategic location far from national borders, but also resources in water and good connections by road and railways.

After the Second World War the economic industrial development continued. In 1947 SCAL resumed its activity. From 1957 the Compagnie Générale de Duralumin and Copper (CEGEDUR) has operated. The Ducellier institutions developed electrical equipment for cars. Although Ducellier establishments stopped production in 1985, the town of Issoire could adapt to conversions. Indeed, the Society for Vehicle Equipment was installed and merged in 1987 with Valeo.

Issoire became a renowned industrial site in the aluminum and metals processing industry (Constellium, Aubert-et-Duval, Interforge) and aerospace and automotive OEMs. Issoire claims as the European leader and global second in the production of thick plates for the aerospace market. Rex Composites (successor of Wassmer Aviation) makes parts subcontracted for aerospace and military industry and develops high-performance materials made from carbon fiber. These advantages make it the economic capital of Val d'Allier Sud territory.

\footnotetext{
${ }^{1}$ In France, a town is defined as an urban unit. The notion of urban unit is based on continuity of built area and the number of inhabitants. It is a municipality or a set of municipalities ( 2 in the case of Issoire) presenting a continuous built zone (no cut of more than 200 meters between two constructions) and with at least 2,000 inhabitants. An urban area is a set of municipalities constituted by an urban pole of more than 10,000 jobs, and by rural districts or urban units among which at least $40 \%$ of the resident population having an employment work in the pole or in the municipalities attracted by it (INSEE, national statistics agency).
} 
The specialization in industry is visible. The employment rate in industry was $30,9 \%$ in 2009 (36,5\% in 1999) for the urban unit. It was $29,1 \%$ for the urban area (as to $34 \%$ in 1999 ), and $22 \%$ at the region level. In spite of the importance of industry, the tertiarisation of the economy is visible and accelerated since 1999. Now, about six in ten employees work in trade and services (mainly in education, health and administration sectors).

In 2010, there were 117 industrial establishments, 7,4\% of the total. This is a quite specialized and concentrated industrial area (aluminum products, automotive equipment production). Constellium, European leader in light alloy aluminum transformation, is the biggest employer of the town with more than 1,500 jobs. In 2005 , the four main firms on the zone were counting one third of the total number of employees. It is the $9^{\text {th }}$ most concentrated employment area in France, with a concentration based on few activities very dependent on international groups, thus creating a structural vulnerability.

The economic diversification (through the planning of economic zones and the implementation of supportive policies for small and medium sized enterprises) is therefore important for local actors. In 1992, the creation of the Technology Park Lavaur-La Béchade $\left(46,000 \mathrm{~m}^{2}\right)$ symbolizes the economic and technological dynamism of the city through the window materials (aluminum) and new materials (polymers and composites). It hosts 40 firms, counts for 365 jobs (2012) and is now equipped with very high-speed network and is one of the most important industrial zones with the Listes zone (with Constellium plant) (Fig. 5). An important issue is nowadays linked with the fact that the municipality of Issoire has no more space to develop (part of the urbanization of the banks of the Allier river is submitted to flood hazards). The spatial and industrial development has to be planned at the level of the community of communes (Issoire Communauté) and of the Pays Issoire Val d'Allier Sud (grouping of municipalities of the southern part of the department).

The demographic situation of the town reflects its economic development (KwiatekSołtys, 2011). However, the demographic changes follow the unfavorable tendencies in terms of aging processes, the emigration, the lower natural growth in towns, but the towns is gaining new inhabitants every year (Kwiatek-Sołtys, 2004).

Myślenice is a small town inhabited by over 18,000 people. The population dynamic for the town between years $2002-2012$ is positive and the value 102,7 is close to the average for small towns in the province. The higher dynamic is characteristic only for towns in the direct influence of Kraków (Niepołomice, Wieliczka). The population growth of the town is caused by the natural growth 3,1\% (average for years 2002-2012), while the average migration balance ratio is $-2,2 \%$. The higher level of natural growth indexes is still traditionally characteristic for the south of Poland, where on the one hand there is a very religious society, and on the other hand this is an area of a long term and long origin emigration, especially to USA and Austria. The population of the town is aging quickly. The share of children (aged $0-14$ ) decreased from $18,6 \%$ in 2002 to $15,8 \%$ in 2012 while the share of $65+$ inhabitants increased from $11,5 \%$ to $14,9 \%$ in 2012 . The positive factor, however, is the stable share of mobile working population group (40,7\% in 2002 and 40,1\% in 2012), which means that the labor force of Myślenice has not been aging yet. 


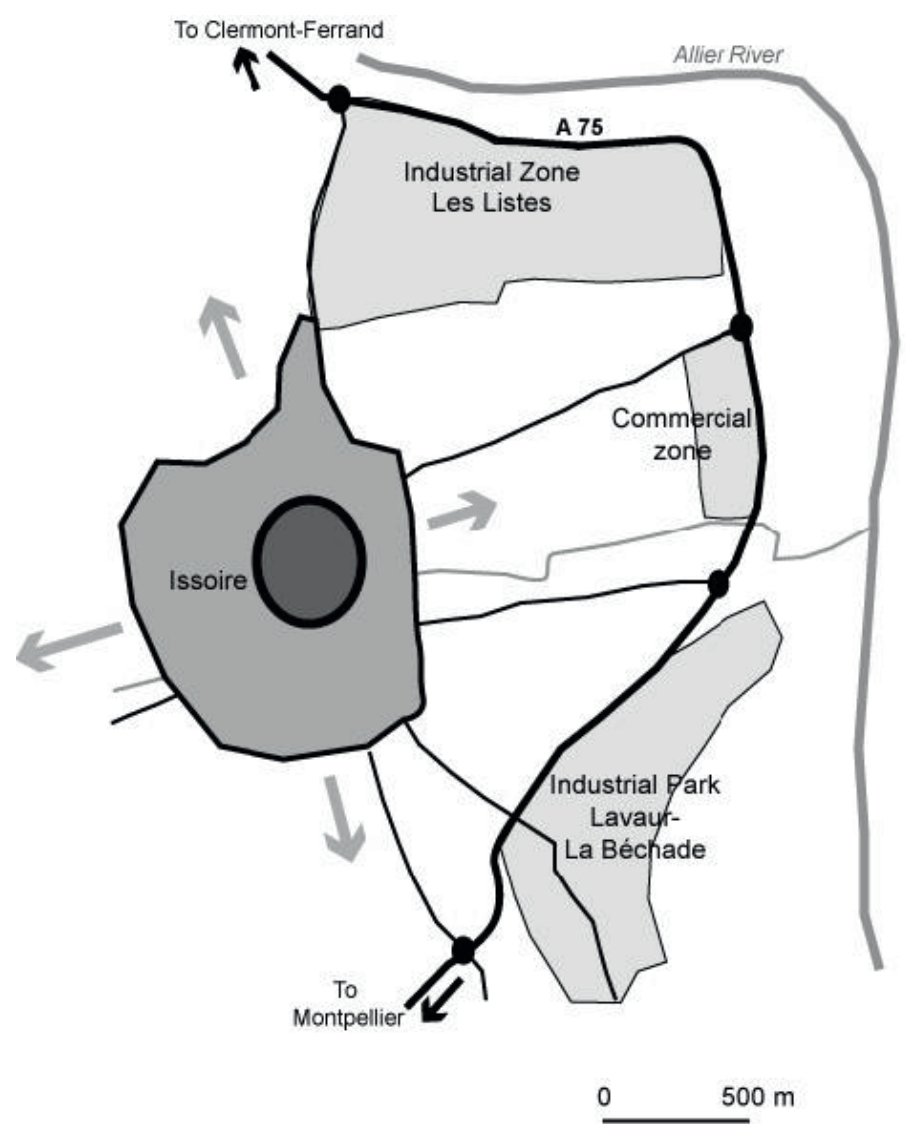

City centre

Pericentral areas

Activity zones

Urban extensions

Motorway

HM-2013

Fig. 5. Industrial zone in Issoire

Source: own elaboration by H. Mainet

The implementation of major industries has changed the face of Issoire and caused a rapid increase in population (8,541 inhabitants in 1954 and 14,771 in 2010). This mutation leads to a population change in the pattern of the city. The development of the urban fabric is characterized by the construction of housing estates and is accompanied by the establishment of community amenities (pool, sports complex). Few functional districts can be clearly seen in the spatial structure of the town. The town's center (Fig. 6 and 7) is located on the west side of the river Allier. The rectangle market square changes into a busy market once a week. New housing estates are being built in the western part of the town. The area along the road 


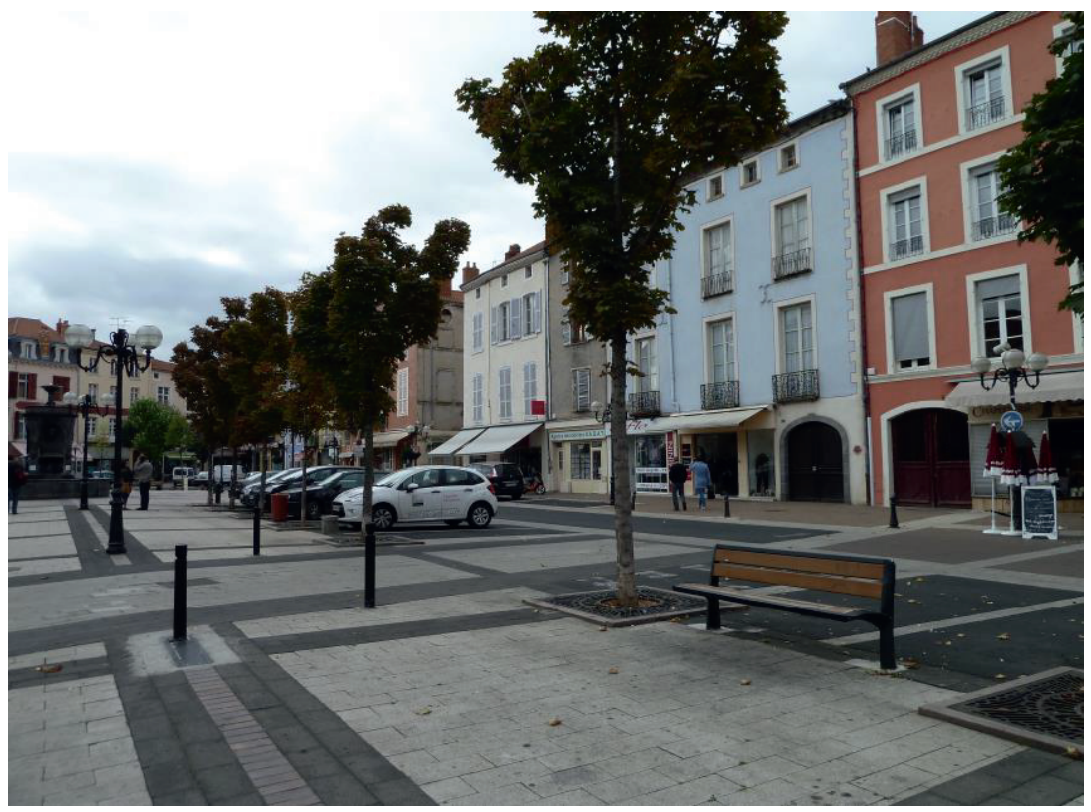

Fig. 6. Issoire - market square

Photo: A. Kwiatek-Sołtys

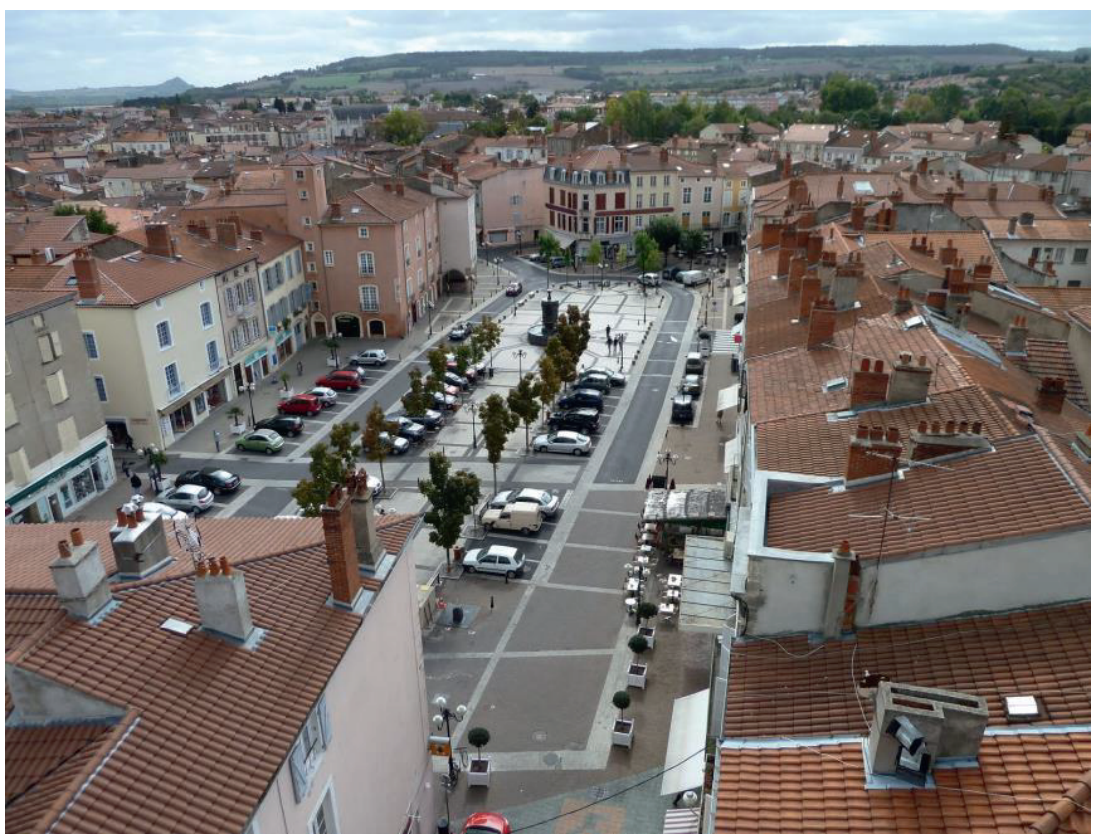

Fig. 7. Issoire - market square

Photo: A. Kwiatek-Sołtys 
A75 is a historical industrial area and the commercial center is located nearby. The eastern part of the town is occupied by the new industry plants and the aviation center together with public and private sports and leisure areas.

In the demographic changes the increase of the urban unit from 14,540 in 1999 to 14,771 in 2009 can be seen. This annual average growth of $0,2 \%$ is even more important at the level of the urban area, with $0,7 \%$ (from 24,575 to 26,367 inhabitants). The population dynamic in recent years is positive for the town (urban unit) thanks to the natural growth; however, the population aging of the society can be seen. The share of children in the town is $16,1 \%$ and for the eldery ( 65 and more) it is $22 \%$ of total population. But the growth of the urban area is mainly due to a positive migration rate in the periurban areas surrounding Issoire (Edouard, 2010).

It is important to look at the location of Issoire: a significant part of its growth is due to the residential attractiveness of households working in the Clermont-Ferrand metropolitan area and looking for nice surroundings and living environment (Mainet, Delaforge, 2011) (Fig. 8). Issoire is included in the periurbanization process of Clermont-Ferrand (the most dynamic municipalities of the urban area are located north of Issoire center, between Issoire and Clermont-Ferrand). The net migration rates are positive for young households with children, while they are negative for students and young adults (leaving for Clermont or for other main towns).

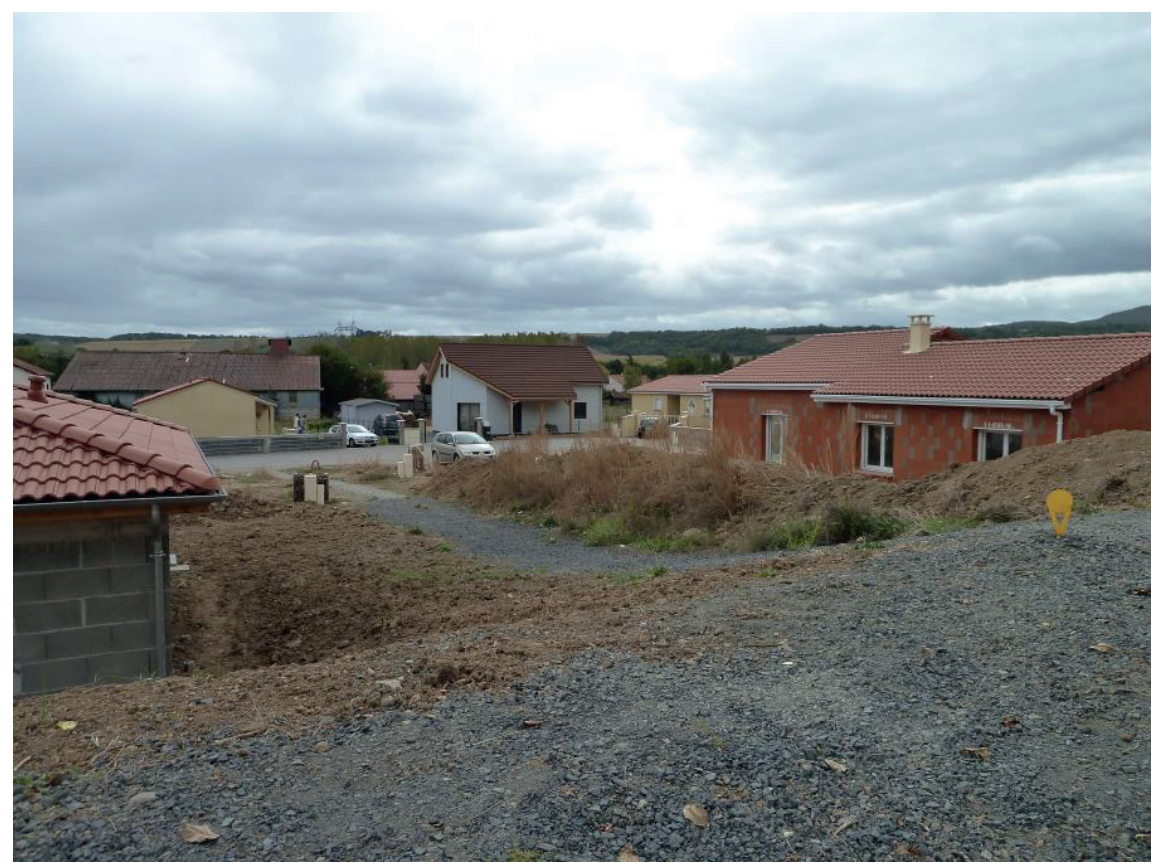

Fig. 8. Issoire - new residential area

Photo: A. Kwiatek-Sołtys 
The number of jobs in the urban unit was 11,349 in 2009 (10,463 in 1999) when the number of residents working in the zone was 5,737 (they were 5,646 in 1999). The share of the population working in the urban unit of all active populaiton living in the urban unit was $63 \%$ (70,2\% in 1999), while 30,7\% was working in other municipalities of the department (24,3\% in 1999); $40,3 \%$ of the active population living in the urban area was working in the urban area (49,4\% in 1999). This means that almost half of the jobs were occupied by workers living outside the urban unit, mainly in the other municipalities of the urban area, but also from other areas. This is an element for the important level of commuting.

A more precise analysis of the profiles of residents and workers show that new periurban residents of Issoire urban unit are quite wealthy households (managers and associate professionals) working outside the area. On the contrary, $46 \%$ of employees working in the area as commuters are workers (but also technicians). There is a mismatch between the profile of jobs and that of residents of the area.

\section{ELEMENTS OF COMPARISON}

The present economic situation of two analyzed towns seems to appear similar due to the nowadays dynamism closely associated with the metropolitan influence (Fig. 9 and 10). The history of the industrial and economic situation is, however, slightly different. While the growth of industry in Myślenice was always influenced by Kraków, for Issoire the industrial development of the town was quite independent of Clermont-Ferrand, with a quite late development in the early $20^{\text {th }}$ century.

The studied towns have a very comfortable situation as far as the location of the mentioned economic zones is concern (Fig. 4 and 5). On the one hand, the zones are located far from the historical center of the towns and are also isolated from the housing estates, which means that they create a separate area in the spatial structure of towns, so there is no conflict with other functions including tourism (Wdowiarz-Bilska, 2009). On the other hand, the location of the zones with an easy reach to big metropolis (Kraków and Clermont-Ferrand) is a pull factor in terms of qualified employment. The zones are well planned and therefore they make a homogeneous area.

Transport to and from the economic zone seems to be also of outstanding importance. A heavy traffic of tracks should not influence the everyday life of towns' inhabitants. From that point of view Myślenice and Issoire are of a privileged situation, as the location of industry is with a direct contact to the country roads. The advantage of Issoire is its' connection to the railway transport, as the town is located on the Paris-Clermont-Méditerranée railway, while there are no railway lines passing through Myślenice. In case of Myślenice conclusions are particularly relevant to the proposed planning solutions in the field of development of transport infrastructure in the region, which is expected in the nearest future. Planning studies are being developed for a new road network in Małopolska region (Albrecht, 2013) and the analysis of effects of improving transport accessibility of the area (Więckowski et al., 2013) are used to determine the benefits of economic development of Małopolska province. 


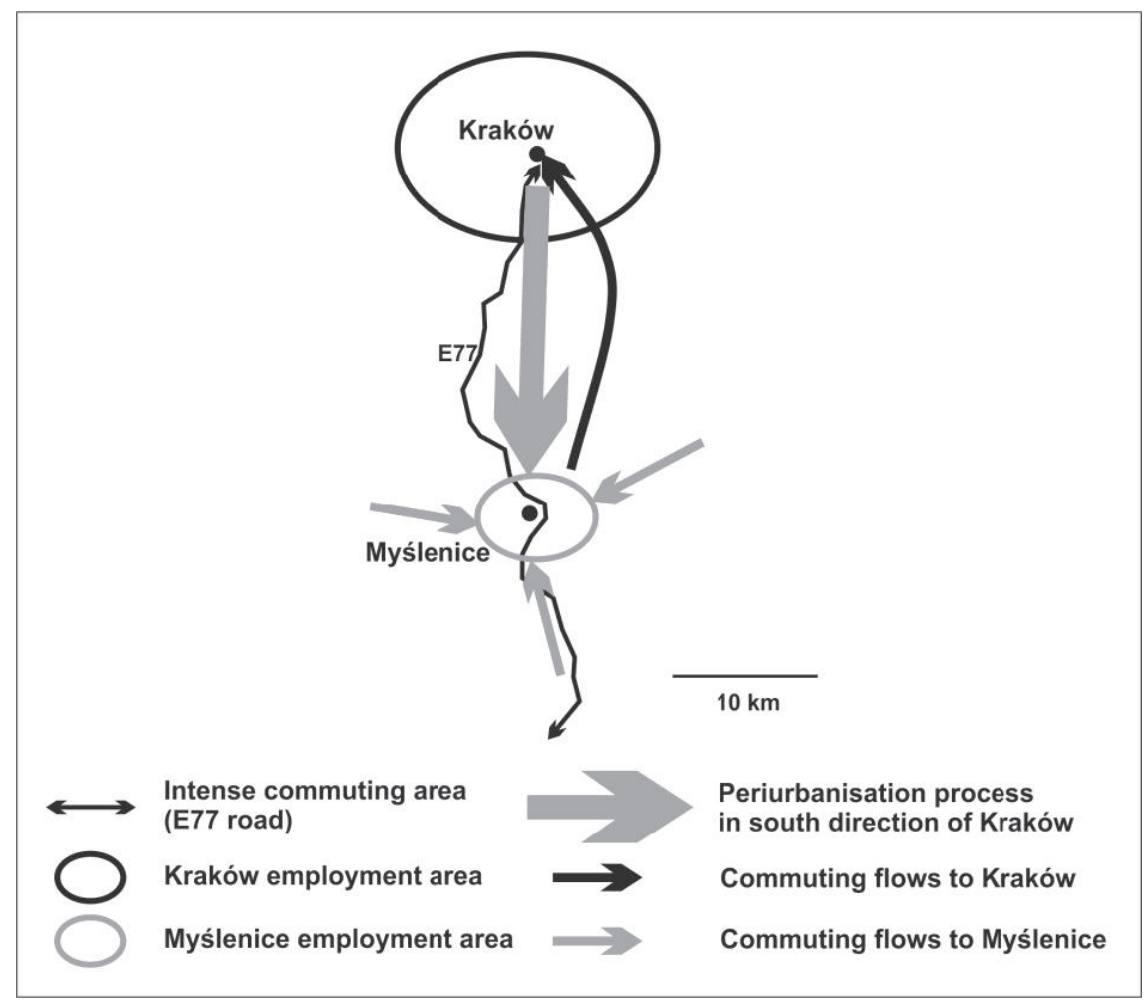

Fig. 9. Metropolisation processes in the area of Kraków-Myślenice

Source: own elaboration by K. Wiedermann

The role of local actors including the towns' authorities and the positive inhabitants' attitude is also an important factor of the growth of such zones. The zones can be developed only thanks to the effort of local authorities, who do their best to attract investors, prepare the sufficient space equipped with the necessary infrastructure and prepare the regulations and solutions for easy law procedures. The positive atmosphere from both authorities and inhabitants are another factor. Two examined towns fill those needs with excellence.

The development of industry in the analyzed cities has had a very positive impact on their socio-economic situation. Although they belong to the group of small towns for which the accumulation of problems causing stagnation or even recession is characteristic today, their situation in the region is relatively better. The situation of the two examined towns on the background of the region, seems to be relatively better due to the development indicators on a slightly higher than average position.It should be remembered, however, that the core areas of each region (Kraków and Clermont-Ferrand) have the strongly privileged position. What is more, the size and role of these metropolitan centers make the average indicators high. An important element expressing the level of development of the town is the income received by the municipality per capita. 


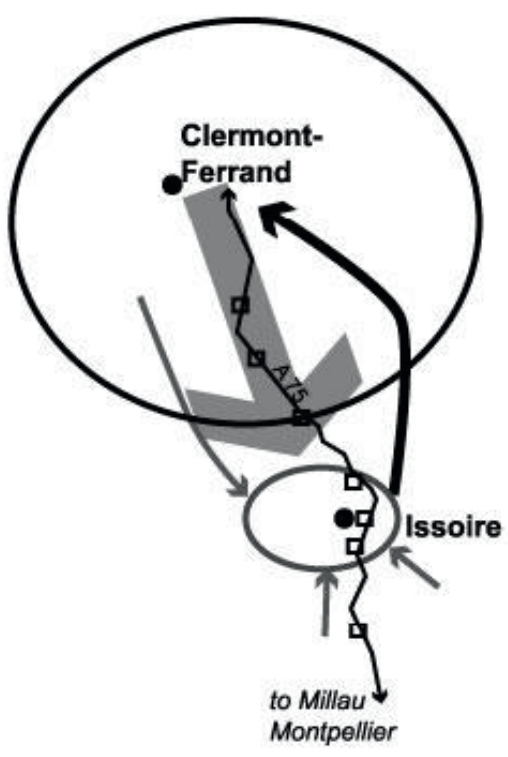

0 $10 \mathrm{~km}$

Intense commuting area

$\leftrightarrow$ A75 Motorway (toll free)

口 Motorway junctions
Clermont-Ferrand polarization

Periurbanisation process in South Val d'Allier

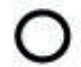

Clermont-Fd employment area

Commuting flows to

Clermont-Fd
Issoire influence

issoire employment area

Commuting flows to Issoire

HM-2013

Fig. 10. Metropolisation processes in the area of Clermont-Ferrand - Issoire

Source: own elaboration by $\mathrm{H}$. Mainet

In the case of Myślenice the relationship between the development of industrial areas and the increase in the municipal budget own revenues can be clearly seen (Fig. 11). The situation of Myślenice in terms of own commune income had been worse than the average for the municipalities of the region till the year 2010. In years 2011-2012, incomes were much higher, which can indicate the correct direction of the development of the city. Another important indicator may be the share of employment among the total population. This indicator shows that in the case of Issoire the socio-economic situation is similar (Fig. 12). The percentage of working people is in this town a bit higher than the average for the whole of Auvergne. It should also be stressed that economic growth for the entire region in years 1999-2009 was significant and resulted in the increase of the percentage of employees by around 4 percentage points. 
Agnieszka Kwiatek-Soltys, Krzysztof Wiedermann,

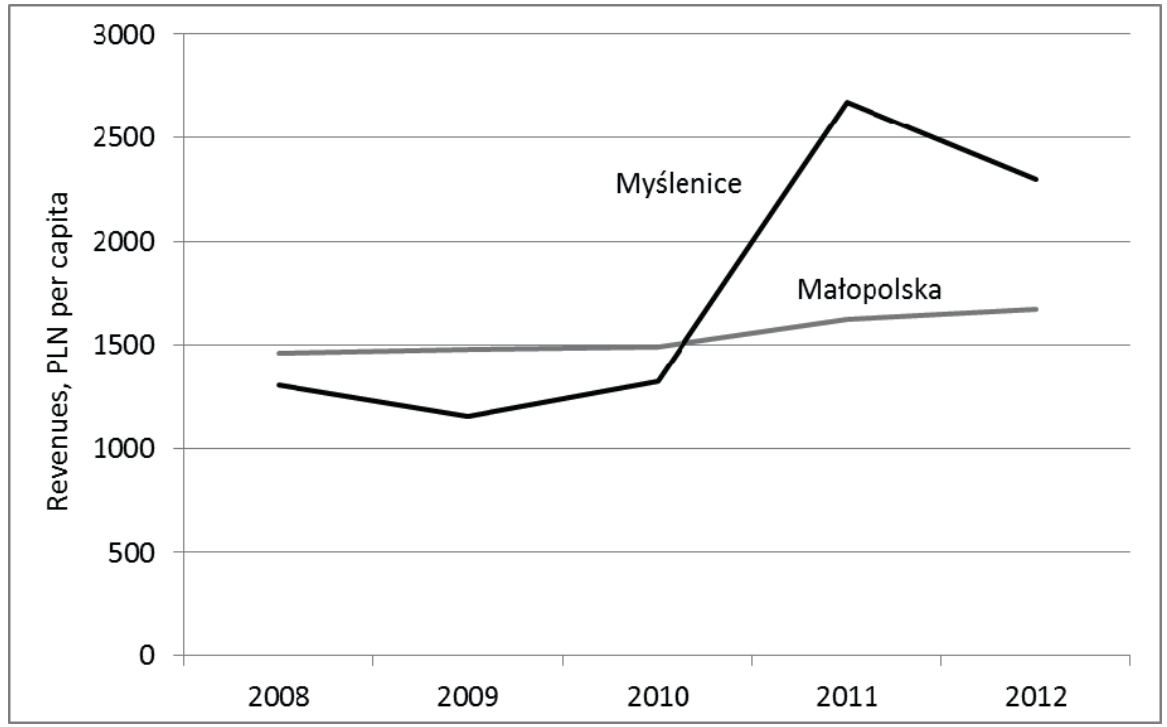

Fig. 11. The comparison of Myślenice and Małopolska region - own revenues of communes Source: own elaboration by K. Wiedermann

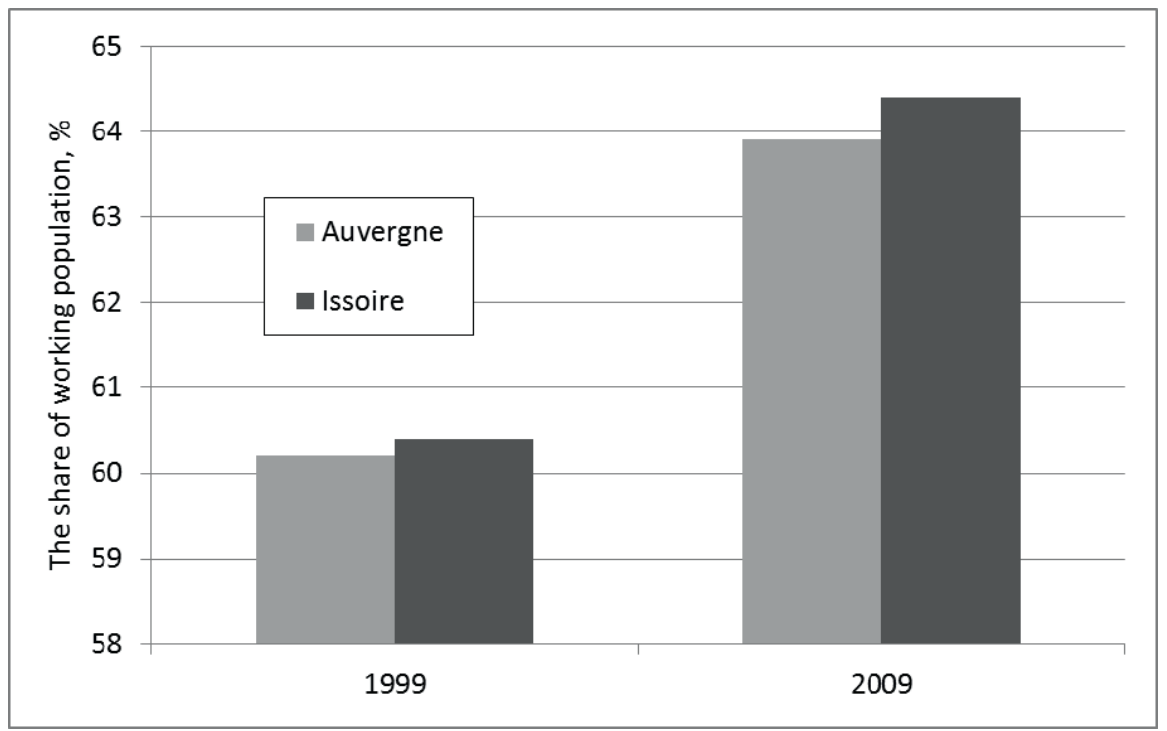

Fig. 12. The comparison of Issoire and Auvergne Region - the share of working population Source: own elaboration by K. Wiedermann 


\section{Conclusions}

Development factors, summarized above, clearly show the high attractiveness of two analyzed towns for the location of industry. The result is thus a constant influx of new investors as a result of the relocation of production within metropolitan areas, as well as from the outside. The success of industrial companies and their positive impact on the development of these centres clearly show that in the case of small satellite towns production function is still very important area of the local economy. It should be considered that the development of production facilities, despite directly created jobs in factories, also features a large multiplier effects. They arise from the development of the network of cooperating companies - both production and service, as well as the relatively higher wages, which relate to the manufacturing sector. An important issue from the point of view of the financial situation of the towns and cities are also taxes paid by the companies, particularly property taxes, due to the fact that the industry is one of the activities carried out over large areas and the amount of tax is primarily determined by the size of the area occupied by the company.

The ongoing positive local development processes of these two cities may become a model for many small towns where the economic base is shrinking. It is often observed that insufficient emphasis in the development strategies is placed on increasing the attractiveness of towns by the location of industrial activities. From planning and regional development point of view Issoire and Myślenice examples also highlight the role of good transport accessibility of small towns to major regional centres, as it is one of the key factors of attractiveness of small towns for the location of production activities.

\section{References}

Albrecht, S. (2013). Rozwój systemu transportu w Małopolsce. In: Przestrzeń publiczna - od użyteczności do kreatywności. Małopolskie Studia Regionalne, 2-3(28-29)/2013, 123-128. Kraków: Departament Polityki Regionalnej, Urząd Marszałkowski Województwa Małopolskiego.

Bilska-Wdowiarz, M. (2009). Nowoczesne strefy przemysłowe w strukturze małych miast i miejscowości w Krakowskim Obszarze Metropolitalnym In: T. Marszał (ed.), Funkcja przemysłowa matych miast. Łódź: Wydawnictwo UŁ.

Domański, B. (2004). Local and regional embeddedness of foreign industrial investors in Poland. Prace Geograficzne, 114, 37-54.

Domański, B., Gwosdz, K., Huculak, M., Wiedermann, K. (2005). Oddziaływanie SSE Euro-Park Mielec na otoczenie lokalne. Powiązania firm i efekty mnożnikowe. In: B. Domański, K. Gwosdz (eds.), Dziesięć lat doświadczeń pierwszej polskiej specjalnej strefy ekonomicznej Mielec 19952005. Kraków: Instytut Geografii i Gospodarki Przestrzennej UJ oraz ARP o. Mielec.

Domański, B., Gwosdz, K. (2010), Multiplier effects in local and regional development. Quaestiones Geographicae, 29(2), 27-38.

Edouard, J.C. (2010). Les petites villes du Massif central. In: L. Cailly, M. Vanier (eds.), La France, une géographie urbaine, collection U, A. Colin, 363, 165-168.

Jarczewski, W., Huculak, M. (eds.) (2011). Sukces polityki proinwestycyjnej. Niepołomice 1990-2010. Wnioski dla władz lokalnych. Kraków: Instytut Rozwoju Miast. 
Kwiatek-Sołtys, A. (2004). Małe miasta województwa małopolskiego w okresie transformacji systemowej. Kraków: Wydawnictwo Naukowe AP.

Kwiatek-Sołtys, A. (2011). Bariers and factors of growth of small towns of Poland. Procedia-Social and Behavioral Sciences, 19, 363-370.

Mainet, H., Delaforge, Q. (2011). Pratiques spatiales des ménages des villes intermédiaires: entre logiques de seuil et effets d'emboîtement. L'exemple du Sud de l'agglomération clermontoise (Issoire et Brioude). In: M. Giroud, H. Mainet, J.-C. Edouard (eds.), Les mobilités spatiales dans les villes intermédiaires. Territoires, pratiques, regulations. PUBP, collection CERAMAC, 29, 197-214.

Marszał, T. (ed.) (2009). Funkcja przemysłowa małych miast. Łódź: Wydawnictwo UŁ.

Rachwał, T., Wiedermann, K. (2008). Multiplier effects in regional development: The case of the motor vehicle industry in Silesian voivodeship (Poland). Quaestiones Geographicae, 27(1), 67-80.

Rachwał, T. (2012a). Innowacyjność przedsiębiorstw przemysłowych jako czynnik rozwoju miast. In: Z. Makieła (ed.), Miasto innowacyjne. Wiedza-Przedsiębiorczość - Marketing. Studia Komitetu Przestrzennego Zagospodarowania Kraju PAN, t. CXLI, Warszawa, 135-152.

Rachwał, T. (2012b). Inwestycje w dużych miastach i obszarach metropolitalnych. In: M.J. Nowak, T. Skotarczak (eds.), Inwestycje w mieście. Uwarunkowania ekonomiczne, organizacyjne i przestrzenne. Warszawa: CeDeWu.pl, Wydawnictwa Fachowe, 195-218.

Rajman, J. (2000, 2001). Sieć osadnicza województwa małopolskiego w okresie transformacji społeczno-gospodarczej. Folia Geographica, Series Geographica-Oeconomica, 31-32, 61-79.

Rajman, J. (2001). Zmienna rola przemysłu jako czynnika miastotwórczego. In: J. Rajman (ed.), Polska - Europa: gospodarka, przemyst. Kraków: Wydawnictwo Naukowe AP, 109-124.

Stryjakiewicz, T. (ed.) (2005). Impact of foreign investors on regional and local development: The case of GlaxoSmithKline Pharmaceuticals S.A. in Poznań. Poznań: Bogucki Wydawnictwo Naukowe.

Wiedermann, K. (2008). Koncepcja efektów mnożnikowych w wyznaczaniu wpływu przedsiębiorstw na otoczenie społeczno-gospodarcze. Prace Komisji Geografii Przemystu Polskiego Towarzystwa Geograficznego, 11, 98-106.

Więckowski, M., Michniak, D., Bednarek-Szczepańska, M., Chrenka, B., Ira, V., Komornicki, T., Rosik, P., Stępniak, M., Székely, V., Śleszyński, P., Świątek, D., Wiśniewski, R. (2013). Pogranicze polsko-słowackie - przestrzeń dla rozwoju. Wyniki badań projektu INFRAREGTUR w zakresie dostępności przestrzennej. In: Przestrzeń publiczna - od użyteczności do kreatywności. Małopolskie Studia Regionalne, 2-3(28-29)/2013, 129-142. Kraków: Departament Polityki Regionalnej, Urząd Marszałkowski Województwa Malopolskiego.

Helene Mainet, Associate Professor in Geography. Ph.D. in Geography in 2000 at Paris-10 Nanterre University. Her research is concentrated on small and medium-sized towns in Europe (especially in France and Poland) and in Africa (their role in urban-rural relationships). Important scientific interests and lectures are placed on urban geography, urban planning and development in non-metropolitan areas. Her most recent works deal with the issues of quality of life and sustainable development policies. She is responsible fora multidisciplinary French research program on attractiveness of intermediate towns.

Jean-Charles Edouard, Professor in Geography. Habilitation in 2007, Ph.D. in Geography in 1999 on the Urban Network in Northern Massif Central in France. His research aims at issues of small and medium-sized towns, urban geography, urban planning, development in non-metropolitan areas in France and Europe. He is responsible for MA's in urban planning and management dedicated to small and medium-sized towns. His recent researches deal with the issues of attractiveness of intermediate towns and on criteria of evaluation (both quantitative and qualitative).

Agnieszka Kwiatek-Soltys, graduated with MA degree and Ph.D. in Geography. Since 1993 she is working at the Institute of Geography of the Pedagogical University of Cracow, lecturing on the geography of settlement, urban geography and urban tourism. She is the author of the book Small Towns of 
Małopolska Province in Transition. Her research interests concentrate on issues related to the functioning of small towns, the place and role of small towns in the urban settlement system, the demography changes and the quality of life of small towns as well as the development issues of small district towns and also spa towns. Her very recent works deal with the problem of land use and the ownership structure of land in small towns.

Krzysztof Wiedermann, Associate professor in the Department of Socio-Economic Geography at the Pedagogical University of Krakow since 2007. His research interests focus on the issues of local and regional development, urban and regional economics, urban restructuring and industrial districts with particular emphasis on relocation of industry and services, foreign direct investment and instruments in support of economic development - the special economic zones, industrial parks.

\section{Adres/address:}

Helene Mainet, Jean-Charles Edouard Université Blaise Pascal, Clermont-Ferrand, France

CERAMAC (Centre for Research on Massif Central, Mountains and Fragile Territories)

Maison des Sciences de l'Homme (House of Human Sciences)

4 rue Ledru, 63000 Clermont-Ferrand, France

e-mail: Helene.MAINET@univ-bpclermont.fr

J-Charles.EDOUARD@univ-bpclermont.fr

\section{Adres/address:}

Agnieszka Kwiatek-Sołtys, Krzysztof Wiedermann

Pedagogical University of Cracow

Department of Socio-Economic Geography

Institute of Geography

ul. Podchorążych 2, 30-084 Kraków, Poland

e-mail: akwiatek@up.krakow.pl

k.wiedermann@up.krakow.pl 